\title{
Insulin Wakayama: familial mutant insulin syndrome in Japan
}

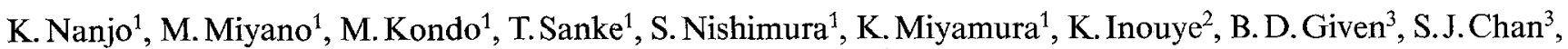 \\ K.S. Polonsky ${ }^{3}$, H.S. Tager ${ }^{3}$, D.F. Steiner ${ }^{3}$ and A.H. Rubenstein ${ }^{3}$ \\ ${ }^{1}$ Department of Medicine, Wakayama University of Medical Science, Wakayama, and ${ }^{2}$ Shionogi Research Laboratories, Osaka, Japan; \\ ${ }^{3}$ Department of Medicine, Biochemistry and Molecular Biology, University of Chicago, Chicago, Illinois, USA
}

\begin{abstract}
Summary. We describe a family from Japan displaying the mutant insulin syndrome with hyperinsulinaemia and an increased insulin:C-peptide molar ratio. Serum insulin isolated from several family members showed reduced in vitro biological activity, and analysis by high performance liquid chromatography revealed a peak co-eluting with human insulin and a second species of increased hydrophobicity co-migrating with the previously reported Insulin Wakayama. The insulin genes from the propositus were cloned and sequenced, revealing one normal allele; the second allele, encoding a leucine for valine amino acid substitution at position 3 of the insulin $A$
\end{abstract}

chain, was similar to that previously described for Insulin Wakayama. Synthesized $\left[\mathrm{Leu}^{\mathrm{A}}{ }^{\mathrm{3}}\right]$ insulin showed $0.14 \%$ of receptor binding activity on rat adipocytes and a 10 -fold prolonged half-life in a somatostatin-infused dog compared with human insulin. The finding of the same mutant gene in two unrelated Japanese families suggests that Insulin Wakayama may be discovered in additional Japanese families with hyperinsulinaemia and/or diabetes.

Key words: Insulin, mutant, familial, gene, high performance liquid chromatography.
Diabetes associated with the synthesis and secretion of a structurally abnormal insulin has been identified in three families with three distinct defects characterized at the genomic level [1-3]. The relationship of the mutation in the insulin gene to the frequently co-existing glucose intolerance is incompletely understood. Additionally, the frequency with which these mutant genes occur in the general population and, therefore, the overall incidence of diabetes associated with abnormal insulins is unknown.

We have identified a fourth family with the mutant insulin syndrome. Characterization of the mutant insulin by high performance liquid chromatography (HPLC) and DNA analysis has confirmed that this family demonstrates the identical point mutation leading to the expression of [Leu $\mathrm{A}^{3}$ ] insulin previously described for Insulin Wakayama [3], and raises the possibility that this genetically transmitted defect may be present in additional Japanese diabetic patients. Additionally, this insulin analog has been synthesized, allowing us to characterize its in vivo and in vitro characteristics.

\section{Subjects and methods}

\section{Subject}

The subject was a 57-year-old, non-obese Japanese man from Arida, Japan, who presented with glucosuria on routine examination. Three years later, he showed increased glucosuria accompanied by thirst and general fatigue. He had no family history of diabetes. Physical examination revealed eczematoid dermatitis on his arms, but he was otherwise normal. Laboratory tests were normal except for marked fasting hyperinsulinaemia $(0.83 \mathrm{pmol} / \mathrm{ml}$; $\mathrm{nl}<0.13)$. Possible causes of hyperinsulinaemia were evaluated. Counterregulatory hormone excess was ruled out (fasting growth hormone $5.8 \mathrm{ng} / \mathrm{ml}$, cortisol $12.6 \mu \mathrm{g} / \mathrm{dl}$, glucagon $97 \mathrm{pg} / \mathrm{ml}$ ). Anti-insulin and insulin antireceptor antibodies $[4,5]$ and islet cell surface antibodies [6] were absent, and binding of ${ }^{125} \mathrm{I}$-insulin to the patient's erythrocyte insulin receptors [7] was normal.

\section{Clinical studies}

An oral glucose tolerance test (OGTT, $50 \mathrm{~g}$ ) and an insulin tolerance test (ITT, $0.1 \mathrm{U} / \mathrm{kg}$ intravenous pure pork insulin) were performed on the subject after an overnight fast. A second OGTT was performed 18 months later, at which time samples were collected for the HPLC study (see below).

To assess whether the defect was hereditary, fasting glucose, immunoreactive insulin (IRI) and C-peptide (CPR) levels were measured in other family members.

\section{Characterization of purified serum insulin}

Insulin isolated by Sep-Pak [8] from the serum of the subject and selected family members was subjected to gel-filtration on Bio-Gel P30 (Bio-Rad, Richmond, Calif, USA) and separation on reverse-phase HPLC as previously described [9]. Serum samples collected from the subject during the second OGTT at baseline and 30,60, 90 and $120 \mathrm{~min}$ after $50 \mathrm{~g}$ of glucose were also subjected to HPLC analysis. 

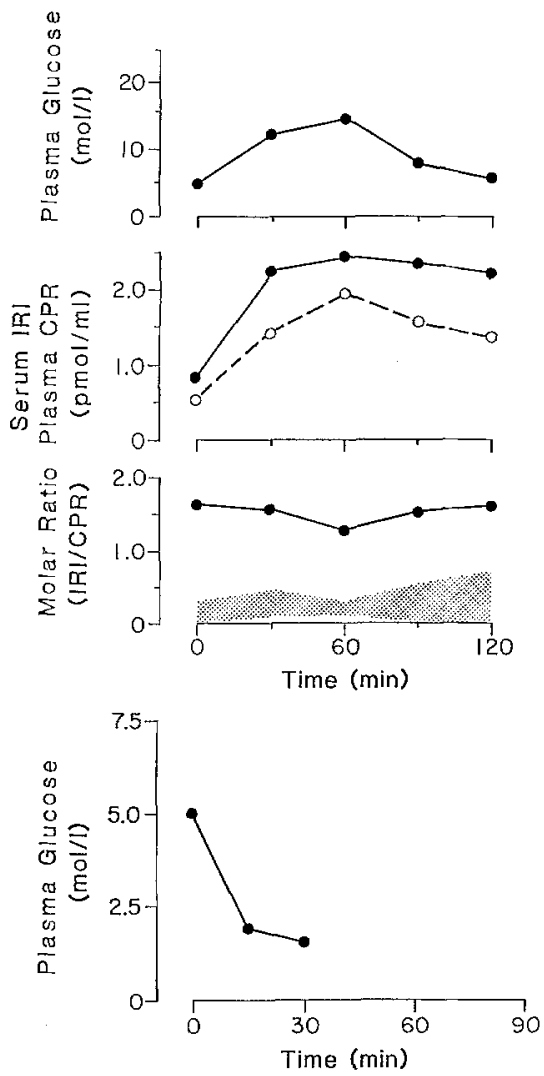

Fig. 1. Changes with time in plasma glucose, insulin immunoreactivity $(\operatorname{IRI})(-$ ), C-peptide immunoreactivity (CPR) $(\mathrm{O} \ldots \mathrm{-}-\mathrm{O})$, and IRI/CPR molar ratios after the oral administration of a 50-g oral glucose tolerance test to the subject. The bottom panel displays the response of plasma glucose to an intravenous bolus injection of $0.1 \mathrm{U} /$ $\mathrm{kg}$ of pork insulin. The test was terminated due to hypoglycaemia at $30 \mathrm{~min}$. The shaded area in the third panel represents mean $\pm 2 \mathrm{SEM}$ for IRI/CPR molar ratios in 30 normal subjects

\section{Insulin-gene characterization}

To determine the coding sequence of the insulin gene, DNA was isolated from peripheral leukocytes obtained from the subject [1]. Both insulin alleles were cloned $[10,11]$ and sequenced [12] according to our published methods $[1,2,11,13]$.

\section{Semisynthetic [Leu $\left.{ }^{4}\right]$ insulin}

$\left[\mathrm{Leu}^{\mathrm{A}}{ }^{3}\right]$ insulin was produced by semi-synthetic methods [14]. The identity of the analog was confirmed by sequence analysis and by comparison with Insulin Wakayama on HPLC (data not shown). Binding of this analogue to insulin receptors was assessed using rat adipocytes [15]. In vivo clearance of the [ $\left.\mathrm{Leu}^{\mathrm{A} 3}\right]$ insulin analog and normal human insulin were measured in the dog according to previously described methods in which the disappearance of insulin from serum is calculated following the abrupt discontinuation of a steady state infusion [16].

\section{Results}

\section{Clinical studies}

The initial OGTT revealed impaired glucose tolerance with a normal fasting plasma glucose of $5 \mathrm{~mol} / 1$ which peaked at $14.4 \mathrm{~mol} / 1$ at $60 \mathrm{~min}$ (Fig.1). This hypergly-

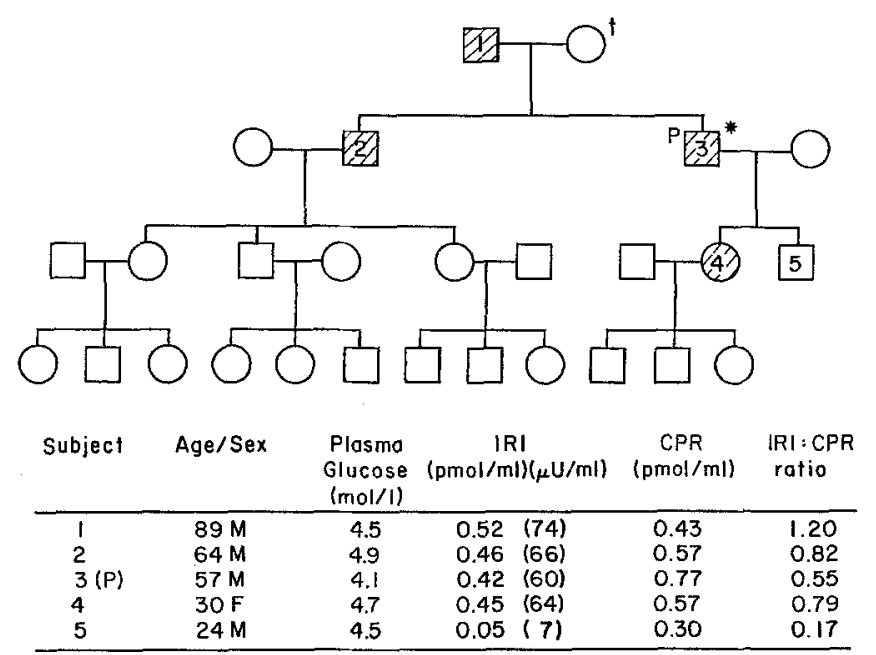

Fig. 2. Pedigree and clinical data for the subject and studied family members. Numbered subjects were available for screening. $P=$ subject, $\dagger=$ deceased. Diagonal lines signify fasting hyperinsulinaemia; the asterisk signifies impaired glucose tolerance. Insulin immunoreactivity (IRI) is expressed as pmol $/ \mathrm{ml}$ with $\mu \mathrm{U} / \mathrm{ml}$ in parentheses. $\mathrm{CPR}=\mathrm{C}$-peptide immunoreactivity

caemia occurred despite pronounced hyperinsulinaemia. In contrast, the plasma C-peptide levels were relatively normal. Resultant IRI/CPR molar ratios were thus markedly elevated (Fig. 1).

To assess insulin sensitivity in vivo, exogenous insulin was administered intravenously. Despite the patient's marked endogenous hyperinsulinaemia, he responded normally to exogenous insulin. The test was terminated due to symptomatic hypoglycaemia at $30 \mathrm{~min}$ (Fig. 1).

To determine whether the hyperinsulinaemia was familial, screening of other family members was arranged. Five family members from three generations were available for study and were willing to cooperate. As shown in Figure 2, four of the five were hyperinsulinaemic with abnormally elevated IRI/CPR molar ratios. None were diabetic, as assessed by fasting plasma glucose levels and the absence of post-prandial glucosuria. They did not agree to have oral glucose tolerance tests.

\section{Characterization of circulating insulin}

Since proinsulin and its intermediates crossreact in the insulin assay and result in elevated IRI levels [17], sera from the subject and his four family members were subjected to size exclusion gel chromatography. The peak co-eluting with ${ }^{125}$ I-insulin accounted for $>90 \%$ of serum IRI in all subjects (data not shown).

Insulin was purified from the serum of the subject and the other four available family members and subjected to reverse phase HPLC analysis (Fig. 3). All four subjects with hyperinsulinaemia demonstrated the presence of a major peak of increased hydrophobicity reacting in the insulin assay. A normal insulin peak was also 
detected on two of the chromatograms, but was not detected at these low concentrations in subjects 1 and 2 . The unaffected son (subject 5) displayed only normal insulin on HPLC analysis.

Because the HPLC pattern closely resembled that of Insulin Wakayama [3, 9], insulins purified from the sera of the index cases from both of the families were chromatographed separately and in combination. The patterns were indistinguishable from each other (data not

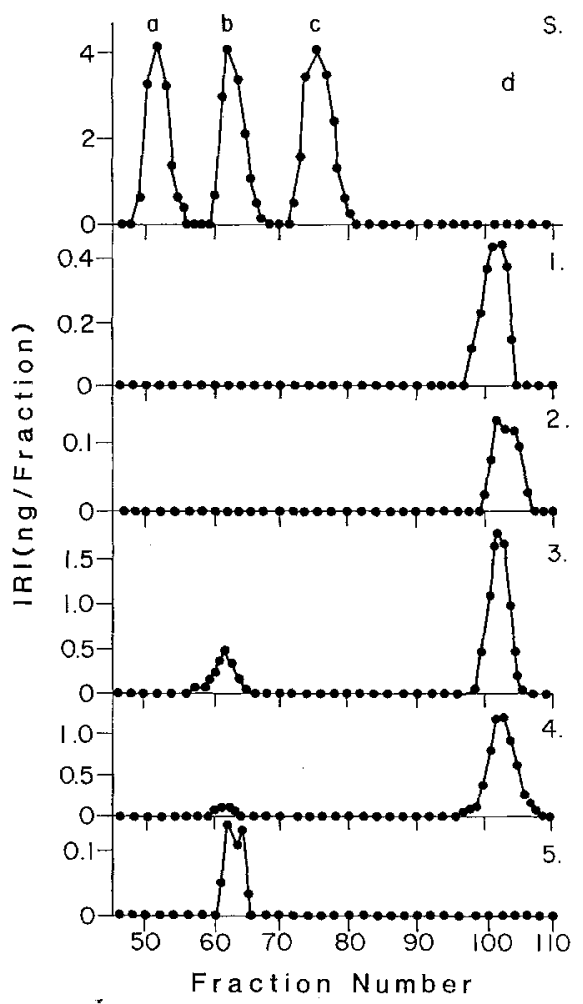

Fig. 3. HPLC analysis of insulin purified from sera obtained from the father (1), brother (2), subject (3), daughter (4) and son (5). Chromatography of a mixture of bovine (a), human (b) and porcine (c) insulins is shown in the upper panel(S). The peak corresponding with $\left[\mathrm{Leu}^{\mathrm{A}}\right]$ insulin is designated (d) shown), a result strongly suggesting that a second family expressing Insulin Wakayama had been identified.

Having observed glucose intolerance during the first OGTT despite the presence of marked hyperinsulinaemia, a second OGTT was performed with samples collected and extracted by Sep-Pak for HPLC analysis. The normal and abnormal insulin peaks were separately quantitated and expressed as a ratio of total HPLC insulin immunoreactivity. By then multiplying this ratio by the total serum IRI level, the actual concentrations of each insulin species at various time points could be calculated (Table 1).

\section{Insulin gene characterization}

To identify the mutation resulting in the expression of $\left[\mathrm{Leu}^{\mathrm{A}}\right]$ insulin in this family, the alleleic insulin genes from the subject were cloned and sequenced using recombinant DNA techniques (Fig.4). One allele contained the normal coding sequence consistent with the presence of normal insulin in the circulation. However, the second allele contained a thymine for guanine substitution in the first position of the triplet normally coding for valine at position 3 in the insulin A chain. This is the identical point mutation previously identified in the insulin gene coding for Insulin Wakayama [3, 11], and results in a leucine for valine substitution. Thus, both families synthesize and secrete $\left[\mathrm{Leu}^{\mathrm{A}}\right]$ insulin as well as normal human insulin.

\section{In vitro and in vivo characterization of semi-synthetic $\left[\mathrm{Leu}^{\mathrm{A}}{ }^{3}\right.$ insulin}

Binding of normal human and semisynthetic $\left[\mathrm{Leu}^{\mathrm{A}}\right]$ insulin to rat adipocytes was compared. As shown in Table 2, there was a greater than 700 -fold reduction in the ability of the analog to displace $50 \%$ of the pork insulin tracer compared to normal human insulin standards. In vivo clearance was assessed in a somatostatin

Table 1. Serum and plasma samples during a $50 \mathrm{~g}$ OGTT in the subject were collected and assayed for glucose, insulin and C-peptide. Insulin was then extracted from serum and separated by HPLC, and normal human insulin (normal) and [Leu ${ }^{\mathrm{A} 3}$ ] insulin (abnormal) were quantitated by insulin radioimmunoassay and expressed as a ratio of the total of both peaks. Multiplying this ratio by the serum insulin level yields the circulating concentration of the two insulin species displayed

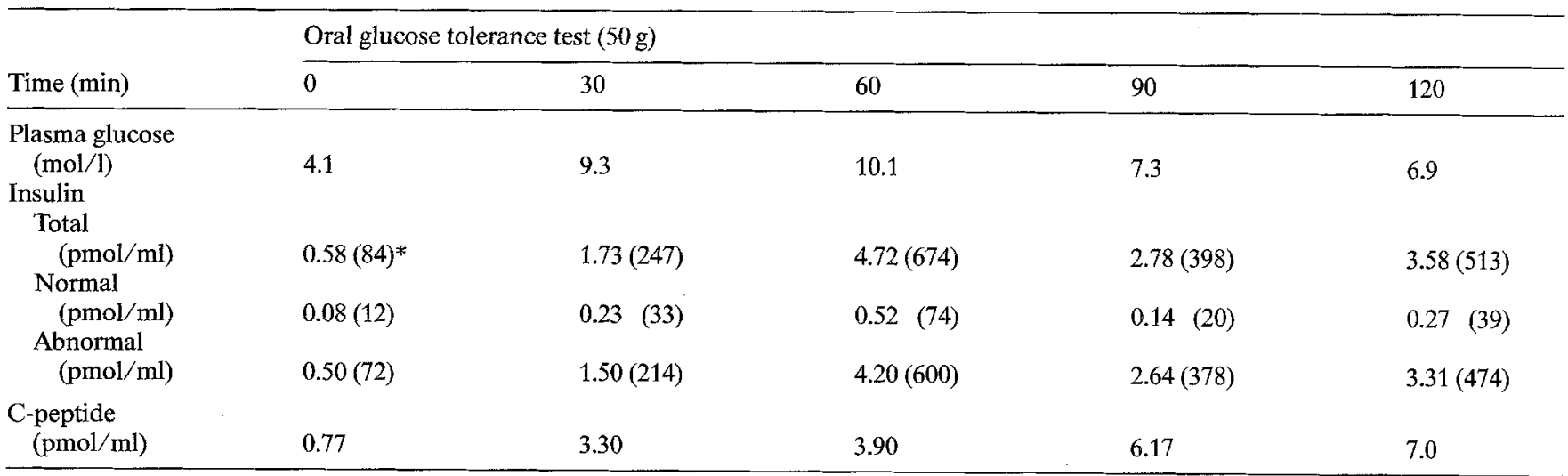

* Values in $\mu \mathrm{U}$ per $\mathrm{ml}$ are in parenthesis 


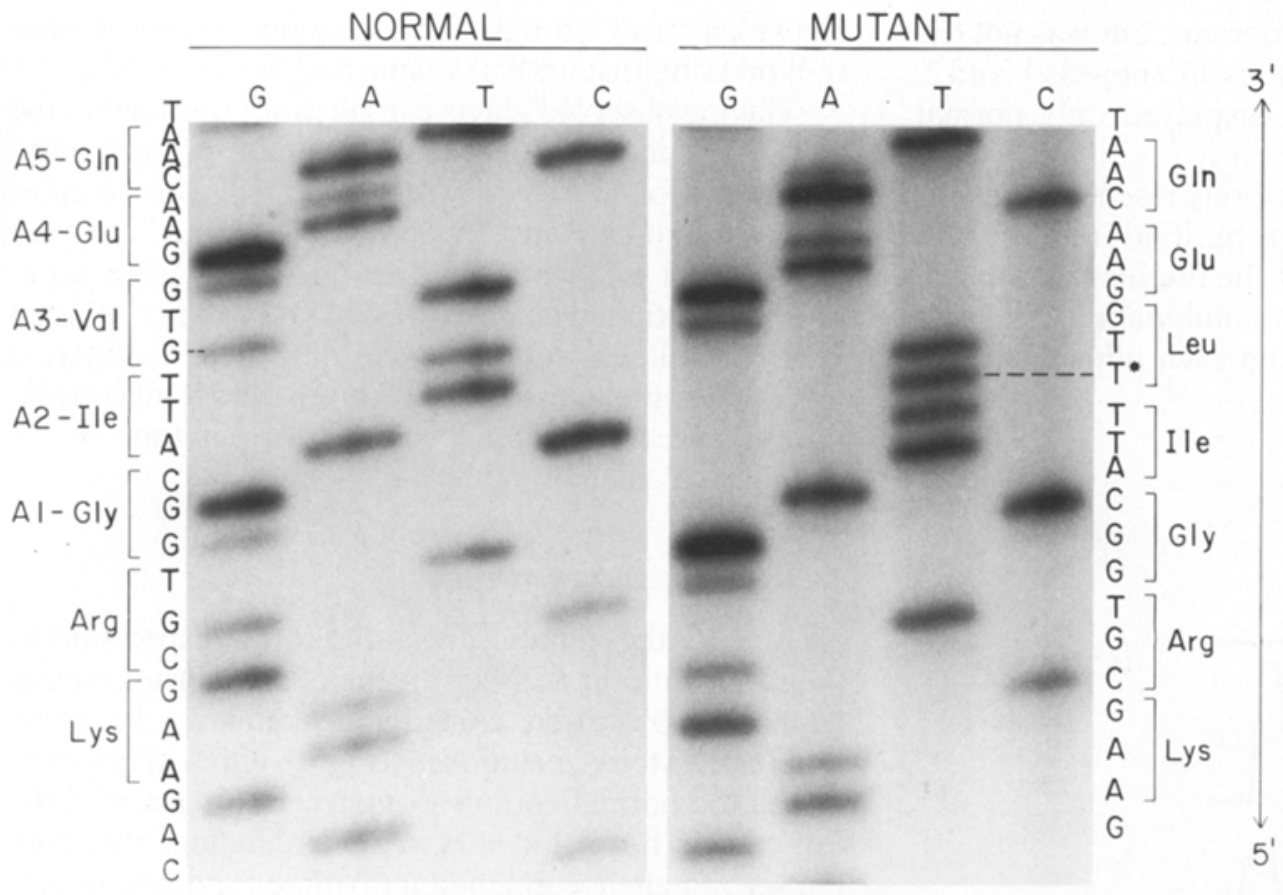

Fig.4. Autoradiograph of portions of the sequencing gel showing the partial nucleotide sequence of both normal and mutant alleles in the area of the point mutation. The single base transversion is indicated by an asterisk $(*)$

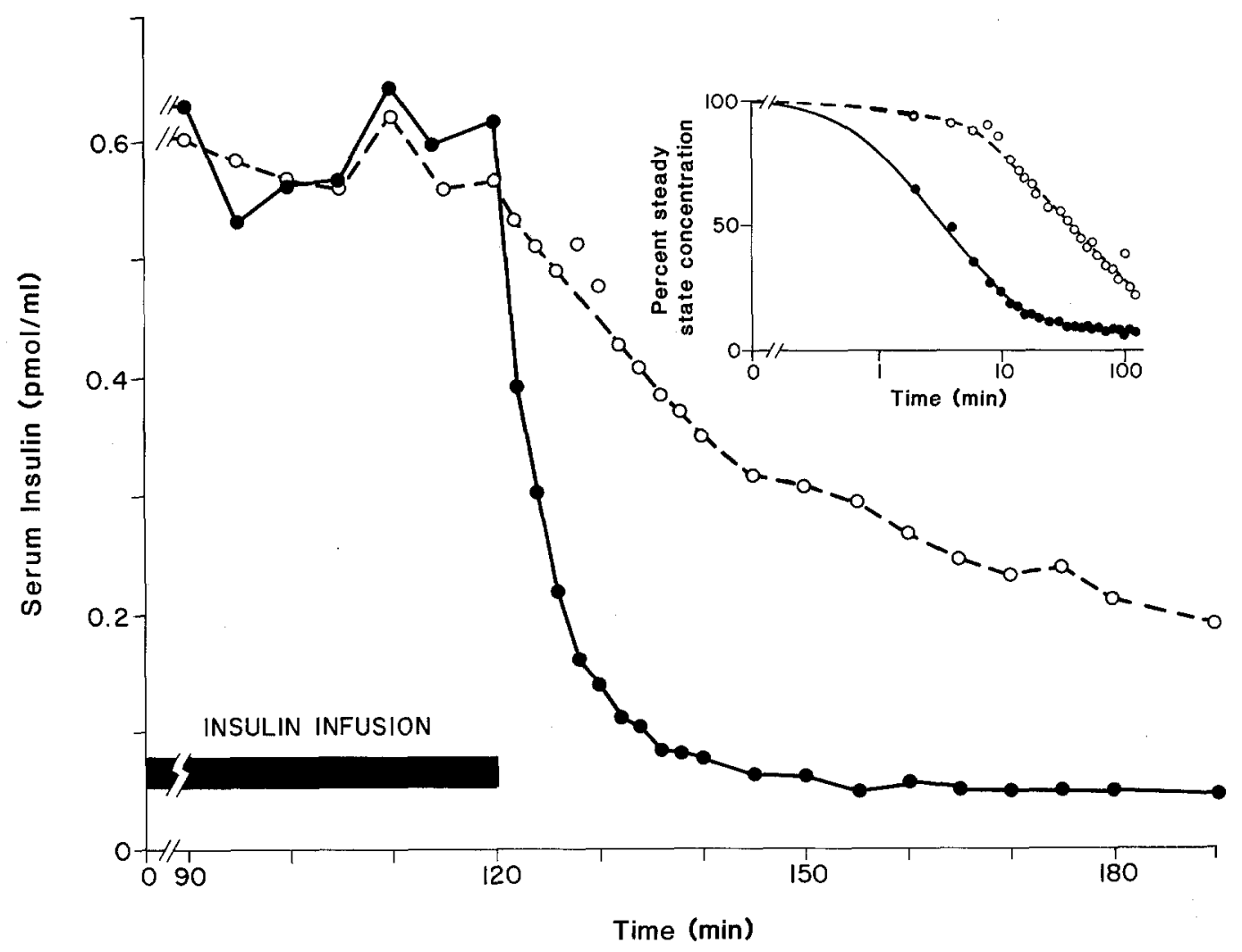

Fig.5. Serum insulin concentrations in a somatostatin infused dog studied on two occasions. On the first, human insulin (-) was infused at a concentration of $1.44 \mathrm{mU} \cdot \mathrm{kg}^{-1} \cdot \mathrm{min}^{-1}$ for $120 \mathrm{~min}$, at which point the infusion was abruptly discontinued and frequent insulin levels drawn. In a separate experiment, semisynthetic [Leu $\left.{ }^{\mathrm{A} 3}\right]$ insulin (O-..-O) was infused at $0.382 \mathrm{mU} \cdot \mathrm{kg}^{-1} \cdot \mathrm{min}^{-1}$ for $120 \mathrm{~min}$ and abruptly discontinued. The insert shows the change in insulin level expressed as a percent of the steady state level following discontinuation of the infusion

infused dog by measuring the half-life following abrupt discontinuation of a steady state infusion of the analog (Fig. 5). A similar experiment employing normal human insulin is included for comparison. A 10 -fold difference in half-life was observed (35.0 vs $3.6 \mathrm{~min}$, Fig. 5 , Table 2).

\section{Discussion}

With the development of the insulin radioimmunoassay and the subsequent finding that many Type 2 (non-insulin-dependent) diabetic subjects possessed normal or even elevated plasma insulin levels, the speculation 
Table 2. Binding potency of human and semisynthetic [Leu $\left.{ }^{\mathrm{A} 3}\right]$ insulins on rat adipocytes expressed in percent (in terms of 50\% displacement of a ${ }^{125} \mathrm{I}$-pork insulin tracer). Human insulin was assigned a value of $100 \%$ for comparison with the analog. Also shown is the clearance half-life $\left(t_{1 / 2}\right)$ following the abrupt discontinuation of human insulin or analog in the somatostatin-infused dog (see also Fig. 5)

\begin{tabular}{llc}
\hline & $\begin{array}{l}\text { Adipocyte binding } \\
(\%)\end{array}$ & $\begin{array}{c}\mathrm{t}_{1 / 2} \\
(\min )\end{array}$ \\
\hline Human insulin & 100 & 3.6 \\
{$\left[\mathrm{Leu}^{\mathrm{A} 3}\right]$ insulin } & 0.14 & 35.0 \\
\hline
\end{tabular}

arose that the insulin molecules in some of these patients might be genetic mutations resulting in biologically less active insulins which still retained immunoreactivity [18]. Since 1978, three such cases have been reported and characterized at the genomic level [1-3, $19,20]$. Other potential mutant species have been identified, but these species await gene confirmation [21, 22].

Studies of affected families have led to the description of the "mutant insulin syndrome" consisting of hyperinsulinaemia, lack of counterregulatory hormone excess or circulating antibodies to insulin or its receptor, demonstration of a normal response to exogenous insulin, increased insulin:C-peptide molar ratio and reduced biological activity of endogenous insulin $[2,3$, 20].

This report describes the fourth such patient characterized at the level of the insulin gene (Fig. 4). As in the other examples $[9,16]$, the predominant circulating insulin form in affected family members is the mutant species (Fig. 3). In two of the family members studied (subjects 1 and 2), normal insulin was not detected in the circulation due to the small quantity of serum analyzed. This predominance of the mutant form in serum has been ascribed to delayed plasma clearance based on two lines of evidence. First, when insulin was extracted from the pancreas of the first patient identified with the mutant insulin syndrome, approximately $50 \%$ was authentic human insulin [9]. Second, when the in vivo clearance of semi-synthetic [Ser $\left.{ }^{\mathrm{B} 24}\right]$ insulin (Insulin Los Angeles) was compared to normal human insulin in the dog, its half-life was markedly prolonged [16]. Equimolar infusions of $\left[\mathrm{Ser}^{\mathrm{B} 24}\right]$ insulin and normal human insulin resulted in the marked accumulation of the abnormal form. Our present findings are in agreement with these results. $\left[\mathrm{Leu}^{\mathrm{A} 3}\right]$ insulin showed a 10 -fold increase in half-life compared to normal human insulin in the dog (Fig.5). Since the clearance of human insulin in dog and man are similar [23, 24], this experiment probably mimics the in vivo situation closely. Moreover, since insulin clearance is closely related to receptor binding, the reduced clearance is presumably due to reduced receptor binding, as suggested by the in vitro rat adipocyte data (Table 2), which showed that $\left[\mathrm{Leu}^{\mathrm{A}}{ }^{3}\right]$ insulin displaced ${ }^{125}$ I pork insulin tracer only $0.14 \%$ as well as the human insulin standard. That a neutral for neutral amino acid substitution results in a marked change in hydrophobicity as demonstrated by the HPLC analysis suggests an underlying alteration in the tertiary structure of this mutant insulin molecule. In addition, the A3 site may be directly involved in the receptor binding surface of the insulin molecule. Three dimensional Xray crystallographic analysis of the mutant insulin will be required to definitively answer this issue.

Perhaps the most perplexing question concerning the mutant insulin syndrome is the inconsistent finding of glucose intolerance or overt diabetes in affected family members. In an attempt to clarify this issue, we separated the serum insulin components circulating during the second OGTT in the subject. The results indicated the presence of normal concentrations of authentic human insulin similar to those observed in healthy subjects [25]. This is in keeping with his normal glucose tolerance at the time. Unfortunately, insufficient serum was available from the initial OGTT to perform the same analyses at a time when he was glucose intolerant. The patient's normal response to exogenous insulin at this time (Fig. 1) indicates that insulin resistance was an unlikely contributor to his glucose intolerance. However, it should be noted that the total serum IRI and Cpeptide levels increased approximately eight times above basal during the second OGTT, which was normal, while in the first test the increase was only 3- to 4-fold. In the interim the patient had been treated with diet and exercise, and his glucose tolerance had improved. The implication is that, assuming the ratio of the abnormal to normal insulin was similar in the two tests, the concentration of the normal insulin would have been relatively low and thus inadequate during the initial OGTT, resulting in a diabetic curve (Fig.1, Table 2).

With the opportunity to study four families secreting mutant insulins, it has become apparent that the expression of a single allele coding for a structurally abnormal insulin is not always associated with diabetes. However, it does appear to increase the risk for the occurrence of this disorder; furthermore, when it coexists with an inherited or acquired defect in pancreatic secretion or peripheral insulin resistance, glucose intolerance is more likely to occur than in subjects with two normal insulin genes. Thus, the expression of diabetes may vary between and within families expressing the same defect depending on the presence or absence of other diabetogenic factors, either genetic or acquired.

We have now had the opportunity to compare two families with the same mutant insulin species. Diabetes was present in 3 of 5 members of the first family [3], while in the family reported in this manuscript only transient glucose intolerance in the index case was noted. When four members of the first family were given oral glucose tolerance tests, the degree of hyperglycaemia correlated inversely with the magnitude of their insulin secretory response as judged by circulating Cpeptide levels. The patient reported in this study showed an initial insulin secretory response which was similar to that seen in the previously described diabetic 
subjects. His second OGTT was normal, and his insulin response during this test compared favourably to normoglycaemic members of both families. It seems reasonable to conclude that maintenance of significant pancreatic insulin secretory reserve can mitigate the effects of the reduced biological activity of the mutant insulin and permit the maintenance of euglycaemia.

Finally, while the mutant insulin syndrome may not generally be a numerically important contributor to the overall incidence of diabetes, in isolated, relatively inbred populations an abnormal insulin gene could have an appreciable impact on the prevalence of Type 2 diabetes. The significance of Insulin Wakayama may thus lie in its gene frequency in the Japanese population. The finding of the same point mutation in two unrelated families living over $100 \mathrm{~km}$ apart and with no common relatives for at least 4 generations is adequate justification for careful consideration of this etiological possibility in diabetic patients, especially those with a strong family history of diabetes. Screening efforts aimed at determining the frequency of this gene in various Japanese population groups using an elevated IRI: C-peptide ratio as a potential marker for the condition are currently underway.

Acknowledgements. The authors wish to thank K. Watanabe, J. Iimuma, W.Pugh, A.H.J.Huen and N. Ditkowsky for valuable technical assistance, and V.Kuvakos and M.Puciata for preparing the manuscript. This study was supported by the Wakayama Nokyo Association (Japan) and grants AM13914, AM13941 and AM20595 (The Diabetes Research and Training Center) from the National Institutes of Health.

\section{References}

1. Kwok SCM, Chan SJ, Rubenstein AH, Poucher R, Steiner DF (1981) Loss of a endonuclease cleavage site in the gene of a structurally abnormal human insulin. Biochem Biophys Res Commun 98: 844-849

2. Haneda M, Polonsky KS, Bergenstal RM, Jaspan JB, Shoelson SE, Blix PM, Wishner WB, Freidenberg G, Tager HS, Steiner DF, Rubenstein AH (1984) Familial hyperinsulinemia due to a structurally abnormal insulin: Definition of an emerging clinical syndrome. N Engl J Med 310: 1288-1294

3. Nanjo K, Sanke T, Miyano M, Okai K, Sowa R, Kondo M, Nishimura S, Iwo K, Miyamura K, Given BD, Chan SJ, Tager HS, Steiner DF, Rubenstein AH (1986) Diabetes due to secretion of a structurally abnormal insulin (Insulin Wakayama): Clinical and functional characteristics of $\left[\mathrm{Leu}^{\mathrm{A} 3}\right]$ insulin. $\mathrm{J}$ Clin Invest 77 : 514-519

4. Goldman J, Baldwin D, Pugh W, Rubenstein AH (1978) Equilibrium binding assay and kinetic characterization of insulin antibodies. Diabetes 27:653-660

5. Flier JS, Kahn CR, Roth J, Bar RS (1975) Antibodies that impair insulin receptor binding in an unusual diabetic syndrome with severe insulin resistance. Science 190:63-65

6. Lernmark A, Freedman ZR, Hofmann C, Rubenstein AH, Steiner DF, Jackson RL, Winter RJ, Traisman HS (1978) Islet-cell-surface antibodies in juvenile diabetes mellitus. N Eng1 J Med 299: $375-380$

7. Gambhir KK, Archer JA, Bradley CJ (1978) Characteristics of human erythrocyte insulin receptors. Diabetes 27: 701-708

8. Cohen RM, Given BD, Licinio-Paixao J, Provow SA, Rue PA,
Frank BH, Root MA, Polonsky KS, Tager HS, Rubenstein AH (1986) Site-specific radioimmunoassay in the analysis of circulating proinsulin in hyperinsulinemic states. Metabolism 35: 1137-1146

9. Shoelson S, Haneda M, Blix P, Nanjo K, Sanke T, Inouye K, Steiner D, Rubenstein A, Tager H (1983) Three mutant insulins in man. Nature 302: 540-543

10. Seed B (1983) Purification of genomic sequences from bacteriophage libraries by recombination and selection in vivo. Nucleic Acids Res 11: 2427-2445

11. Bell GI, Karam JH, Rutter WJ (1981) A polymorphic DNA region adjacent to the $5^{\prime}$ end of the human insulin gene. Proc Natl Acad Scie USA 78: 5759-5763

12. Sanger F, Nicklen S, Coulson AR (1977) DNA sequencing with chain-terminating inhibitors. Proc Natl Acad Sci USA 75: $5463-5467$

13. Haneda M, Chan SJ, Kwok SCM, Rubenstein AH, Steiner DF (1983) Studies on mutant human insulin genes: Identification and sequence analysis of a gene encoding Ser B24 insulin. Proc Natl Acad Sci USA 80: 6366-6370

14. Inouye $K$, Watanabe $K$, Tochino $Y$, Kobayashi M, Shigeta $Y$ (1981) Semisynthesis and properties of some insulin analogs. Biopolymers 20: 1845-1858

15. Rodbell M (1964) Metabolism of isolated fat cells. The effects of hormones on glucose metabolism and lipolysis. J Biol Chem 239: 375-380

16. Shoelson SE, Polonsky KS, Zeidler A, Rubenstein AH, Tager HS (1984) Human insulin B24 (Phe $\rightarrow$ Ser). Secretion and metabolic clearance of the abnormal insulin in man and in a dog model. $J$ Clin Invest 73: 1351-1358

17. Robbins DC, Tager HS, Rubenstein AH (1984) Biological and clinical importance of proinsulin. N Engl J Med 310: 1165-1175

18. Conn JW, Fajans SS (1961) The prediabetic state: a concept of dynamic resistance to a genetic diabetogenic influence. Am J Med 31: $839-850$

19. Tager H, Given B, Baldwin D, Mako M, Markese J, Rubenstein A, Olefsky J, Kobayashi M, Kilterman O, Poucher R (1979) A structurally abnormal insulin causing human diabetes. Nature 282: $122-125$

20. Given BD, Mako ME, Tager HS, Baldwin D, Markese J, Rubenstein AH, Olefsky J, Kobayashi M, Kolterman O, Poucher R. (1980) Diabetes due to secretion of an abnormal insulin. N Engl J Med 302: 129-135

21. Seino S, Funakoshi A, Fu ZZ, Vinik A (1985) Identification of insulin variants in patients with hyperinsulinemia by reversed-phase high-performance liquid chromatography. Diabetes 34:1-7

22. Iwamoto Y, Sakura H, Ishii Y, Okayama K, Yokota O, Kumakura S, Hsieh SD, Sakamoto Y, Matsuda A, Kuzuya T (1985) A new case of familial hyperinsulinemia with diabetes probably due to a structurally abnormal insulin. Diab Ewa Clin Pract Suppl 1: 264

23. Polonsky K, Jaspan J, Emmanouel D, Holmes K, Moossa AR (1983) Differences in the hepatic and renal extraction of insulin and glucagon in the dog: evidence for saturability of insulin metabolism. Acta Endocrinol 102: 420-427

24. Sherwin RS, Kramer KJ, Tobin JD, Insel PA, Liljenquist JE, Berman M, Andres R (1974) A model of the kinetics of insulin in man. J Clin Invest 53: 1481-1492

25. Castro A, Scott JP, Grettie DP, Macfarlane D, Bailey RE (1970) Plasma insulin and glucose responses of healthy subjects to varying glucose loads during three-hour oral glucose tolerance tests. Diabetes 19: 842-851

Received: 13 October 1986

and in revised form: 16 December 1986

Dr. A.H. Rubenstein

Department of Medicine

University of Chicago

5841 S. Maryland Ave.

Chicago, IL 60637

USA 